\title{
A Review of the Environmental Effects and Benefits of Selected Solar Energy Technologies
}

Kathryn A. Lawrence
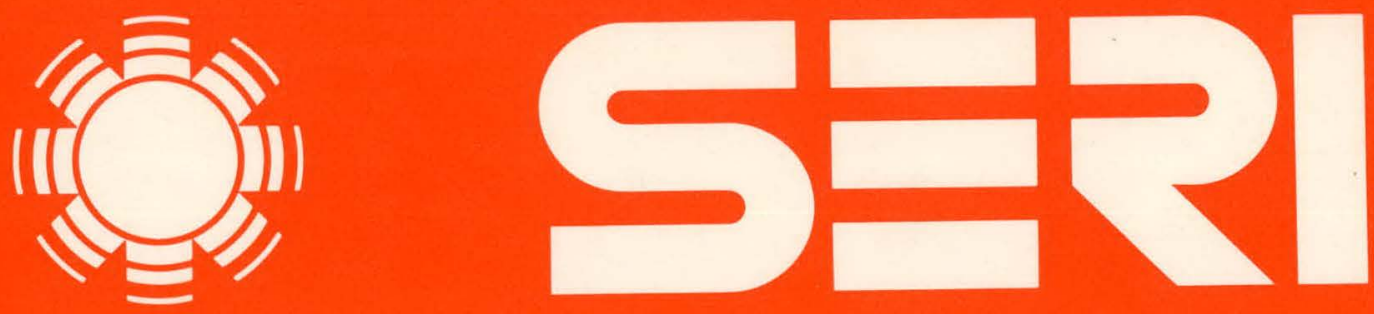

Solar Energy Research Institute A Division of Midwest Research Institute

1536 Cole Boulevard

Golden, Colorado 80401

Operated for the U.S. Department of Energy under Contract No. EG-77-C-01-4042

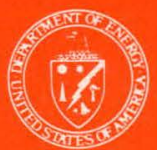




\section{DISCLAIMER}

This report was prepared as an account of work sponsored by an agency of the United States Government. Neither the United States Government nor any agency Thereof, nor any of their employees, makes any warranty, express or implied, or assumes any legal liability or responsibility for the accuracy, completeness, or usefulness of any information, apparatus, product, or process disclosed, or represents that its use would not infringe privately owned rights. Reference herein to any specific commercial product, process, or service by trade name, trademark, manufacturer, or otherwise does not necessarily constitute or imply its endorsement, recommendation, or favoring by the United States Government or any agency thereof. The views and opinions of authors expressed herein do not necessarily state or reflect those of the United States Government or any agency thereof. 


\section{DISCLAIMER}

Portions of this document may be illegible in electronic image products. Images are produced from the best available original document. 
Printed in the United States of America Available from:

National Technical Information Service

U.S. Department of Commerce

5285 Port Royal Road

Springfield, VA 22161

Price:

Microfiche $\$ 3.00$

Printed Copy $\$ 4.00$

NOTICE

This report was prepared as an account of work sponsored by the United States Government. Neither the United States nor the United States Department of Energy, nor any of their employees, nor any of their contractors, subcontractors, or their employees, makes any warranty, express or implied, or assumes any legal liability or responsibility for the accuracy, completeness or usefulness of any information, apparatus, product or process disclosed, or represents that its use would not infringe privately owned rights. 
SER I TPP-53-114R

REVISED: MAY 1979

UC CATEGORY:

A REVIEW OF THE ENVIRONMENTAL EFFECTS AND BENEFITS OF SELECTED SOLAR

ENERGY TECHNOLOGIES

KATHRYN A. LAWRENCE

SEPTEMBER 1978

This report was prepared as an sccount of work sponsored by the United States Govemment. Neither the United States nor the United States Department of Energy, nor any of their employees, nor any of their Energy, hor any of their employees, nor any of their contractors. subcontraciors. of their emolovees, makes any warranty, express or implied, or assumes any legal liability or responsibility for the accuracy, completeness or usefulness of any information, apparatus, product of process disclosed, or represents that its use wninth not infringe privately owned rights.

\section{Solar Energy Research Institute}

1536 Cole Boulevard

Golden, Colorado 80401

A Division of Midwest Research Institute

Prepared for the U.S. Department of Energy

Contract No. EG $\cdot 77 \cdot \mathrm{C} \cdot 01 \cdot 4042$ 


\section{FOREWORD}

This paper was prepared in support of a larger SERI study, the Social Costs and Benefits of Solar Energy. Results of this work were presented at the American Nuclear Society Topical Meeting, Environmental Aspects of Non-Conventional Energy Resources-II, September 26-29, 1978.

\section{Robut Oollend \\ Robert Odland, Chief Institutional and Environmental Assessment Branch}

Approved for

SOLAR ENERGY RESEARCH INSTITUTE

Melvin K. Simmons, Assistant Director

Analysis and Assessment Division 


\section{TABLE OF CONTENTS}

\section{Page}

Abstract $\ldots \ldots \ldots \ldots \ldots \ldots \ldots \ldots \ldots \ldots \ldots \ldots \ldots \ldots \ldots \ldots \ldots \ldots \ldots \ldots \ldots \ldots \ldots$

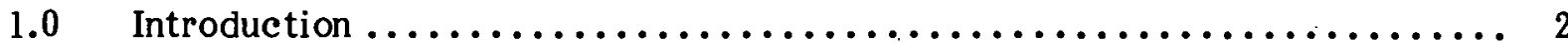

2.0 Environmental Impacts of Resource Extraction and Component Production ................................ 3

3.0 Environmental Effects of Plant Construction.................. 6

$4.0 \quad$ Environmental Eff ects of Plant Operation $\ldots \ldots \ldots \ldots \ldots \ldots \ldots \ldots \ldots$

5.0 Environmental Effects of Plant Decommission $\ldots \ldots \ldots \ldots \ldots \ldots \ldots \ldots$

$6.0 \quad$ Conclusions $\ldots \ldots \ldots \ldots \ldots \ldots \ldots \ldots \ldots \ldots \ldots \ldots \ldots \ldots \ldots \ldots \ldots \ldots \ldots$

Ref erences ....................................... 12 


\section{LIST OF TABLES}

Page

2-1 Resource Requirements and Availability ................... 4

2-2 Indirect Emissions from WECS Material Acquisition and Processing .................................... 5

6-1 Comparison of Coal and Si-Photovoltaic Cell Power Plants........... 11 


\begin{abstract}
No method of energy production is without some environmental effects. Solar energy technologies are no different. This paper briefly reviews and summarizes data on the environmental effects of three solar energy technologies: photovoltaic cells, wind energy conversion (WEC), and the solar thermal central receiver. Potential effects are identified for each of the life cycle phases: resource extraction and component manufacture, plant construction, operation and decommission. The solar energy technologies are assumed to be deployed as a centralized energy production facilities. The technologies examined are materials intensive compared to fossil fuel plants with the same power rating. As a result, the life-cycle phase of resource extraction and component production is the most environmentally hazardous. Impacts of plant construction will be somewhat site specific but should approximate impacts associated with any large construction activity. The operation phase is relatively environmentally benign. None of the options emit sulfur oxides, nitrogen oxides, particulates, hydrocarbons, or carbon monoxide unless auxiliary fossil fuel energy backup systems are incorporated. WEC operation does produce low-level noise pollution and presents minimal hazards to flying species. Solar thermal facilities equipped with wet cooling towers may affect local air quality via cooling tower drift. In addition, large installations of each option may alter local microclimate. Decommission of WEC, solar thermal, and $\mathrm{Si}$-photovoltaic facilities should present no-environmental hazards, although disposal of $\mathrm{CdS}$ or GaAs cells will require care. Total life-cycle impacts of the selected solar energy options are less than for advanced coal fired power plants. Although emissions from resource extraction, processing, and component manufacture are significant for the three solar technologies, cumulative emissions from coal extraction and combustion for 20 to 30 years of coal plant operation far outweigh life-cycle emissions associated with the solar energy options.
\end{abstract}




\section{SECTION 1.0}

\section{INTRODUCTION}

Solar electric technologies have been termed the most environmentally benign sources of electricity yet.conceived. This is certainly true of the plant operation phase (i.e., the period during which electricity is generated and supplied to the consumer) compared to fossil fuel alternatives. However, no form of energy production is without potential environmental impacts including electricity produced by photovoltaic cells, wind energy conversion (WEC), or solar thermal central receiver (power tower) systems. This paper examines potential environmental impacts through use of critical path analysis of each option's life-cycle phases-resource extraction and component production, plant construction, plant operation, and plant decommission. Impacts attributable to energy storage subsystems are not extensively addressed. Section 6.0 summarizes life-cycle environmental impacts and discusses the environmental benefits of displacing conventional energy production technologies by the three selected solar energy technologies. 


\section{SECTION 2.0 \\ ENVIRONMENTAL IMPACTS OF RESOURCE EXTRACTION AND COMPONENT PRODUCTION}

Solar energy is diffuse. Large quantities of equipment are required for collection, concentration, and subsequent conversion of radiant energy into electricity. As a result, solar energy conversion plants are more materials intensive than fossil fuel plants having an equal power production rating. Table 2-l summarizes data on resource requirements and availability. All three solar options discussed here require significant commitments of land, steel, and aluminum for support structures. Extensive land use is particularly characteristic of the WEC systems. Although the base of the WEC occupies a small area (approximately 0.13 hectare, 0.33 acre $[7,12]$ ), significant quantities of land are required for safety zones and for proper unit spacing to assure that the wake of one WEC unit does not inhibit energy collection of another. Minimum spacing has been tentatively established at 10 to 15 rotor diameters $[1,9]$.

Estimates of resource requirements in Table 2-1 are in metric tons per megawatt rating. Assuming deployment levels of $1,000 \mathrm{MW}$ for each technology by the year 2,000, significant increases in raw material processing and/or resource constraints may develop. For all materials except sulfur, projected U.S. demand for all purposes in the year 2,000 exceeds projected production. However, data do not include the materials available through recycling processes, or improvement in system efficiency which would decrease materials requirements. Thus, predictions of resource constraints on photovoltaic, WEC, or power tower deployment are tenuous.

Environmental impacts occur both during mining and processing of raw materials and during fabrication of solar energy module components. Production of cadmium sulfide (CdS) photovoltaic cells (largely a laboratory process at present) is accomplished by spray or vacuum deposition of $\mathrm{CdS}$ and $\mathrm{Cu}_{2} \mathrm{~S}$ on float glass or copper foil. In addition to particulate releases of $.08 \mathrm{~kg} / \mathrm{MT}(0.2 \mathrm{lb} / \mathrm{T})$ cadmium per ton mined, production of 10 $\mathrm{MW}_{\mathrm{e}}$ CdS cells (requiring $454 \mathrm{MT}$ [500 T] cadmium ore) may emit $31 \mathrm{MT}$ (34T) cadmium and 47 MT (52T) cadmium sulfide plus unspecified quantities of cadmium oxide fumes [5]. Cadmium compounds are quite toxic (TLV of $0.05 \mathrm{mg} / \mathrm{m}^{3}$ [16]) to humans and animals and can be bioaccumulated [14]. It should be noted, however, that emissions attributable to photovoltaic cell production are low compared to total U.S. cadmium emissions (e.g., emissions from $10,000 \mathrm{MW}$ cell production is about $5 \%$ of emissions from zine refining alone [5]). In addition, technological changes will probably occur before CdS cells are produced in commercial quantities, which may significantly alter emissions occuring from production processes.

Materials required for WEC and solar thermal components fabrication are not exotic. Aluminum, concrete, copper, fiberglass, and steel are presently produced in significant quantities. Additional demands from deployment of WEC and central receiver facilities should not pose severe environmental hazards stemming from resource requirements. However, as shown in Table 2-2 for WFC systems, significant levels of pollutants will be released during component manufacture if large numbers of systems are deployed. However, these incremental emissions are low compared to current emissions from the materials processing industries. 


\begin{tabular}{|c|c|c|c|c|c|c|}
\hline Material & $\begin{array}{c}\text { Land Use } \\
\mathrm{km}^{2}\left(\mathrm{mi}^{2}\right) / \text { GWle }\end{array}$ & & $\begin{array}{l}\text { MT(T) per } \\
\text { MWe Rating }\end{array}$ & $\begin{array}{c}\text { Domestic } \\
\text { Resources; } \\
\text { MT }(T) \\
\end{array}$ & $\begin{array}{l}\text { Domestic Primary } \\
\text { Production in } \\
\text { 2000; MT(T) }\end{array}$ & $\begin{array}{r}\text { Domestic Primal } \\
\text { Demand Nonsola } \\
\text { Uses in } 2000 ; M\end{array}$ \\
\hline \multicolumn{7}{|c|}{ PHOTOVOLTAIC SYSTEHS } \\
\hline $\begin{array}{l}\text { - Silicon Cells } \\
\text { Silicon }\end{array}$ & $\begin{array}{l}6-8.81 / \\
(2.3-3.4)\end{array}$ & ' & $\begin{array}{l}10 \\
(11)\end{array}$ & $\begin{array}{l}\text { unconstrained } \\
\therefore \text { not estimated }\end{array}$ & $\begin{array}{l}0.9 \times 10^{4} \\
\left(1.0 \times 10^{4}\right)\end{array}$ & $\left(\begin{array}{l}1.1 \times 10^{4} \\
\left(1.2 \times 10^{4}\right)\end{array}\right.$ \\
\hline $\begin{array}{l}- \text { CdS Cells } \\
\text { Cadmium }\end{array}$ & & & $\begin{array}{l}.05 \\
(.05)\end{array}$ & $\begin{array}{l}1614 \times 10^{3} \\
\left(1,780 \times 10^{3}\right)\end{array}$ & $\begin{array}{l}4.5 \times 10^{3} \\
\left(5.0 \times 10^{3}\right)\end{array}$ & $\left(12.5 \times 10^{3}\right)$ \\
\hline Sulfur & $\begin{array}{l}11.7^{1 /} \\
(4.5)^{1 /}\end{array}$ & & NA $\underline{2}$ & $\begin{array}{l}571 \times 10^{6} \\
\left(630 \times 10^{6}\right)\end{array}$ & $\begin{array}{l}22 \times 10^{4} \\
\left(24 \times 10^{4}\right)\end{array}$ & $\begin{array}{l}21 \times 10^{4} \\
\left(23 \times 10^{4}\right)\end{array}$ \\
\hline Copper & - & & NA & $\begin{array}{l}643 \times 10^{6} \\
\left(709 \times 10^{6}\right)\end{array}$ & $\begin{array}{l}3.4 \times 10^{4} \\
\left(3.8 \times 10^{4}\right)\end{array}$ & $\begin{array}{l}3.8 \times 10^{4} \\
\left(4.2 \times 10^{4}\right)\end{array}$ \\
\hline $\begin{array}{r}\text { - GaAs Cells } \\
\text { Gallium }\end{array}$ & $\begin{array}{l}5.5 \frac{1}{1 /} \\
(2.1)\end{array}$ & & $0.27 \times 10^{3} \mathrm{~kg}$ & $4.5 \times 10^{6} \mathrm{~kg}$ & $20 \times 10^{3} \mathrm{~kg}$ & $32 \times 10^{3} \mathrm{~kg}$ \\
\hline Arsenic & & & $0.14 \times 10^{3} \mathrm{~kg}$ & $\begin{array}{l}4.6 \times 10^{6} \\
\left(5.1 \times 10^{6}\right)\end{array}$ & $\begin{array}{l}4.6 \times 10^{2} \\
\left(5.1 \times 10^{2}\right)\end{array}$ & $\begin{array}{l}24 \times 10^{3} \\
\left(26 \times 10^{3}\right)\end{array}$ \\
\hline Aluminum & & & $\begin{array}{l}50-90 \\
(55-99)\end{array}$ & $\begin{array}{l}45 \times 10^{6} \\
\left(50 \times 10^{6}\right)\end{array}$ & $\begin{array}{l}1.9 \times 10^{4} \\
\left(2.1 \times 10^{4}\right)\end{array}$ & $\begin{array}{l}19 \times 10^{4} \\
\left(21 \times 10^{4}\right)\end{array}$ \\
\hline
\end{tabular}

\section{WINO ENERGY CONVERSION SYSTEMS}

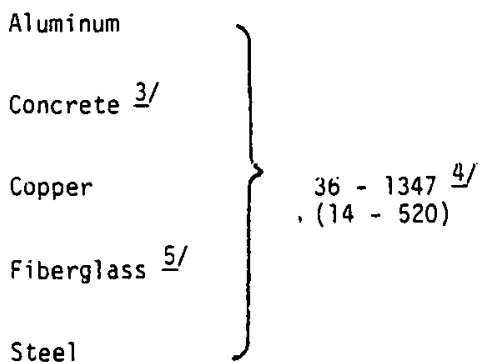

Steel

\section{SOLAR THERMAL CENTRAL RECEIVER SYSTEMS}

$\left.\left.\begin{array}{l}\text { Aluminum } \\ \text { Concrete } \underline{3} / \\ \text { Copper } \\ \text { Glass } \underline{5} / \\ \text { Silver } \\ \text { Steel } \\ \text { Rock } \\ \text { Heat Transfer } 0 i 1\end{array}\right\} \begin{array}{c}52-78) \\ (20-30) \\ \end{array}\right\}$

$$
\begin{aligned}
& 3.7-7.2 \\
& (4.1-7.9) \\
& 224-253 \\
& (247-279) \\
& 2.1-2.3 \\
& 2.3-2.5) \\
& 11-17 \\
& (12-19) \\
& 189-254 \\
& (208-280
\end{aligned}
$$

$$
45 \times 10^{6}
$$$$
\left(50 \times 10^{6}\right)
$$

$18-45$
$(20-50)$
$1361-2268$
$(15 n n-25 n)$
$5-9$
$(5-10)$
$1-2$
$(1-2)$
$45-93$
$(50-102)$
$0.005-0.05$
$(0.005-0.05)$
$454-635$
$(500-700)$
1143
$(1150)$
141
$(155)$

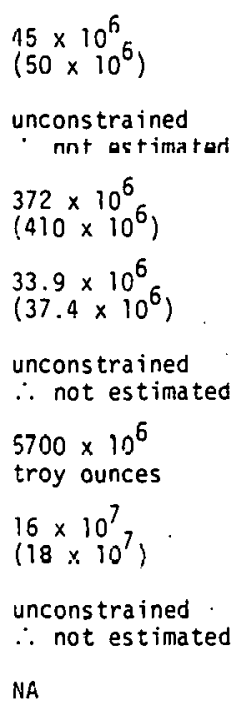

$\begin{array}{ll}1.9 \times 10^{4} & 19 \times 10^{4} \\ \left(2.1 \times 10^{4}\right) & \left(21 \times 10^{4}\right) \\ 113 \times 10^{6} & 195 \times 10^{6} \\ \left(125 \times 10^{6}\right) & \left(215 \times 10^{6}\right) \\ 3.4 \times 10^{4} & 5.4 \times 10^{8} \\ \left(3.8 \times 10^{4}\right) & \left(6.0 \times 10^{6}\right) \\ 24 \times 10^{6} & 24 \times 10^{6} \\ \left(26 \times 10^{6}\right) & \left(26 \times 10^{6}\right) \\ 24 \times 10^{7} & 22 \times 10^{7} \\ \left(26 \times 10^{7}\right) & \left(24 \times 10^{7}\right)\end{array}$

$1.9 \times 10^{4}$

$\left(2.1 \times 10^{4}\right)$

$\left(113 \times 10^{6} \times 10^{6}\right)$

$3.4 \times 10^{4}$

$\left(3.8 \times 10^{4}\right)$

$19 \times 10^{4}$ $\left(21 \times 10^{4}\right)$

$195 \times 10^{6}$ $\left(215 \times 10^{6}\right)$

$5.4 \times 10^{6}$

$-0-$

$\left(1,039 \times 145 \times 10^{3}\right)$

$24 \times 10^{6}$

$\left(26 \times 10^{6}\right)$

$50 \times 10^{6}$

troy ounces

$24 \times 10^{6}$

$\left(26 \times 10^{6}\right)$

$2.30 \times 10^{6}$

$24 \times 10^{7}$
$\left(26 \times 10^{7}\right)$

$23 \times 10^{3} 8$

$\left(25 \times 10^{8}\right)$

NA troy ounces

$22 \times 10^{7}$

$\left(2,4 \times 10^{7}\right)$

$23 \times 10^{8}$

$\left(25 \times 10^{8}\right)$

NA

TABLE 1. RESOURCE REOUIREMENTS ANO AVAILABILITY II

i) Data does not include land required for access roads and transmission lines.

T) NA: not available.

3/ Resource, production, and demand data are for cement; concrete is a mix of cement, sand, and gravel in ratios of $1: 2: 4$ or $1: 3: 5$.

4/ Lower figure is for wind farm with close unit spacing and optional wind regime; higher figure is for $15-r o t o r$ diameter unit spacing, low wind velocity regime, and large safety zones.

5/ Resource, prodiction, and demand data are for alass-grade sand.

6/ Data for chromium and titanium are summed.

7f Source: Table developed by SERI based on information in references 1 to 11. 
TABLE 2

INDIRECT EMISSIONS FROM WECS MATERIALS ACQUISITION AND PROCESSING*

\begin{tabular}{|c|c|c|c|c|c|c|c|}
\hline \multirow{3}{*}{$\begin{array}{c}\text { Material/WEC } \\
\text { Unit Size } \\
\end{array}$} & \multicolumn{7}{|c|}{ Air Emissions } \\
\hline & \multirow[b]{2}{*}{ Particulates } & \multirow{2}{*}{$\mathrm{SO}_{2}$} & \multirow[b]{2}{*}{$\mathrm{CO}$} & \multirow{2}{*}{$\mathrm{NO}_{2}$} & \multicolumn{3}{|c|}{ Fluorides } \\
\hline & & & & & Unspecified & $\mathrm{HF}$ & Particulates \\
\hline \multicolumn{8}{|l|}{ Aluminum } \\
\hline $500 \mathrm{~kW} \mathrm{NC \dagger}$ & $299(394) 6$ & NAT & NA. & NA & NA & $26(58)$ & $20(26)$ \\
\hline $500 \mathrm{~kW} \mathrm{C} \dagger$ & $6(13)$ & iNA & $\mathrm{NA}^{\circ}$ & NA & NA & $0.3(0.9)$ & $.0 .4(0.4)$ \\
\hline $1000 \mathrm{~kW} \mathrm{NC}$ & $1,231(3,127)$ & NA & NA & NA & NA & $105(458)$ & $04(207)$ \\
\hline $1000 \mathrm{~kW} \mathrm{C}$ & $25(103)$ & NA & NA & NA & NA & $1(7)$ & $1.7(3.5)$ \\
\hline $1500 \mathrm{~kW}$ & $\rightarrow-$ No Informat $i$ & on Availabl & $e--$ & & & & \\
\hline \multicolumn{8}{|l|}{ Concretet* } \\
\hline \multicolumn{8}{|l|}{ Dry Process } \\
\hline $500 \mathrm{~kW} \mathrm{NC}$ & 11,616 & 347 & NA & 88 & NA & INA & NA \\
\hline $500 \mathrm{~kW} \mathrm{C}$ & 104 & & NA & 00 & NA & NA & NA \\
\hline $.1000 \mathrm{~kW} \mathrm{NC}$ & $13,324-14,691$ & $398-439$ & -NA & $101-112$ & N.A & NA & NA \\
\hline $1000 \mathrm{~kW} \mathrm{C}$ & $178-263$ & לטיל & NA & $101-212$ & NA & NA & $\mathrm{NA}$ \\
\hline $1500 \mathrm{~kW} \mathrm{NC}$ & $19,815-29,381$ & $592-877$ & NA & $151-224$ & NA & NA & NA \\
\hline $1500 \mathrm{~kW} \mathrm{C}$ & $178-263$ & & NA & & NA & $\mathrm{NA}$ & NA \\
\hline \multicolumn{8}{|l|}{ Wet Process } \\
\hline $500 \mathrm{~kW} \mathrm{NC}$ & 8,862 & 347 & NA & 88 & NA & NA & NA \\
\hline $.500 \mathrm{~kW} \mathrm{C}$ & 104 & 346 & NA & 00 & NA & $\mathbf{N A}$ & NA \\
\hline $1000 \mathrm{~kW} \mathrm{NC}$ & $10,165-11,208$ & $398-439$ & NA & $101-112$ & NA & $\mathrm{NA}$ & $N A$ \\
\hline $1000 \mathrm{~kW} \mathrm{C}$ & $178-263$ & $550-437$ & NA & $\frac{1}{9} 01-112$ & NA & $\mathrm{NA}$ & NA \\
\hline $1500 \mathrm{~kW} \mathrm{NC}$ & $15,117-22,415$ & $592-877$ & NA & $15 i-224$ & NA & NA & NA \\
\hline $1500 \mathrm{~kW} \mathrm{C}$ & $178-263$ & $\begin{array}{c}x>017 \\
.\end{array}$ & NA & $131-264$ & NA & $\mathrm{NA}$ & $\mathrm{YA}$ \\
\hline \multicolumn{8}{|l|}{ Copper } \\
\hline $500 \mathrm{kls}$ & $11-31$ & $\mathrm{NA}$ & NA & NA & NA & NA & NA \\
\hline $1000 \mathrm{~kW}$ & $23-26$ & NA & NA & NA & NA & NA & NA \\
\hline $1500 \mathrm{kw}$ & 13 & NA & NA & NA & NA & NA & $\mathrm{NA}$ \\
\hline \multicolumn{8}{|l|}{ Fiberglass } \\
\hline $500 \mathrm{~kW}$ & $170-95$ & $0.1-101$ & $5 \cdot 3-22$ & $4-63$ & $0.3-2$ & & \\
\hline $1000 \mathrm{~kW}$ & $755-1,087$ & $0.5-120$ & $23-26$ & $19-76$ & $1-2$ & & \\
\hline $1500 \mathrm{~kW}$ & $535-1,767$ & $0.3-195$ & $17-42$ & $13-i 23$ & $1-4$ & & \\
\hline \multirow{7}{*}{$\begin{array}{l}\text { Steel } \\
500 \mathrm{~kW} \mathrm{NC} \\
500 \mathrm{~kW} \mathrm{C} \\
1000 \mathrm{~kW} \mathrm{NC} \\
1000 \mathrm{~kW} \mathrm{C} \\
1500 \mathrm{~kW} \mathrm{NC} \\
1500 \mathrm{~kW} C\end{array}$} & & $\cdot$ & & & & & \\
\hline & $16,707-25,800$ & $233-300$ & $14,061-193,300$ & NA & NA & $8-10$ & $2-24$ \\
\hline & $198-6,528$ & NA & $4,811-6,200$ & NA & NA & $0.1-10$ & $\mathrm{Neg}-1.0$ \\
\hline & $21,530-51,137$ & $300-595$ & $181,200-383,121$ & NA & $N A$ & $10-20$ & $3-47$ \\
\hline & $255-12,938$ & NA & $6,200-12,288$ & NA & NA & $0.1-20$ & $\mathrm{Neg}-2.0$ \\
\hline & $20,604-45,176$ & $287-525$ & $173,40 z-338,463$ & $\mathrm{NA}$ & NA & $10-18$ & $3-42$ \\
\hline & $244-11,430$ & $\mathrm{NA}$ & $5,933-10,856$ & NA & NA & $0.1-18$ & $\mathrm{Neg}-2.0$ \\
\hline \multicolumn{8}{|c|}{$\begin{array}{l}\text { Figures derived by SERI from data in Table } 1 \text { and Reference } 13 \text {. } \\
\text { NC = no pollution abatement; } C=\text { pollution control. } \\
\text { Number outside parentheses is total particuiates (bauxite grinding, Al-manutacture, and materials } \\
\text { handing) for plant using prebaked reduction cells; numbers inside parentheses are for plants using } \\
\text { Suderberg cells and processing the higher amount of Al required for tho WEC unit. } \\
\text { NA = not available. }\end{array}$} \\
\hline
\end{tabular}




\section{SECTION 3.0}

\section{ENVIRONMENTAL EFFECTS OF PLANT CONSTRUCTION}

Central station photovoltaics and central receiver plants will probably be initially sited in desert areas because of the favorable solar insolation and land availability. Thus, environmental impacts associated with construction activities will be very similar for the two solar energy options.

Typical site preparation activities will include site grading, construction of access roads (if necessary), transport of components, construction of the central receiver tower, and assembly and placement of heliostats and photovoltaic arrays. Site preparation will temporarily degrade local air quality via fugitive dust and construction vehicle exhausts $[5,17,18]$. Construction of a $5 \mathrm{MW}_{\text {th }}$ central receiver plant will generate an estimated 2.7 MT (3.0 T) carbon dioxide, 0.5 MT (0.5 T) hydrocarbons, and 5.4 MT $(6.0 \mathrm{~T})$ nitrogen oxides [18]. Desert crust and desert pavement (protective, erosion-resistant surface layers) in the construction area will be destroyed producing increases in wind and water erosion $[3,4]$. These impacts would occur for any large construction project.

Most burrowing desert species spend daytime hours underground to escape the heat. Excavation and site grading, which will be performed during daylight hours, may destroy large numbers of burrowing species. Construction activities, noise, and other activities noxious to wildlife will force emigration of mobile species and destroy many less mobile and sessile species [3-5, 17, 18]. Impacts on local desert ecosystems may be somewhat mitigable by siting photovoltaic and cèntral receivers in sparsely populated desert playas $[3,4]$.

Suitable WEC sites occur throughout the United States. WEC components (e.g., aluminum or fiberglass blades, steel truss towers, generators) will arrive at the site in prefabricated form. Therefore, on-site construction time is expected to be short-six to nine months $[1,7,9,19]$. As with photovoltaic and solar thermal central receiver plants, construction will be comprised of two phases: site preparation and WEC assembly. Site preparation will require four to six months. Local air quality will be affected by vegetation removal which will increase wind erosion and affect local temperature and relative humidity, and by fugitive dust and exhausts attributable to construction equipment. Local water quality will also undergo temporary degradation via enhanced runoff attributable to vegetation removal and site grading, release of oil and grease from construction equipment, and toxic residues if pesticides are used at the site. WEC assembly will require two to three months, depending on worker experience and tower design (e.g., concrete towers are anticipated to require less assembly time than steel truss towers). Transport of materials and erection of ten $1.5 \mathrm{MW}$ WEC units will generate an estimated $1.7 \mathrm{MT}(1.9 \mathrm{~T})$ carbon dioxide, $0.5 \mathrm{MT}(0.6 \mathrm{~T})$ hydrocarbons, and 7.5 MT (8.3T) nitrogen oxides [19]. Impacts on wildlife will be short lived. As with the photovoltaic and solar thermal central receiver systems, impacts will be similar to any large construction operation. Construction activities will destroy sessile species and force emigration of mobile species [1,7, 19]. Since the base of the WEC units will occupy only a small percentage of the total site land area, limited disturbance of land during construction may allow rapid site recovery. 


\section{SECTION 4.0}

\section{ENVIRONMENTAL EFFECTS OF PLANT OPERATION}

Many of the environmental effects associated with operating photovoltaic and solar thermal central receiver plants sited in desert areas will be similar. Land use for both options is significant. The presence of large numbers of heliostats and photovoltaic arrays will modify local terrain, species composition, and microclimate. Wind and water erosion will increase due to desert crust and/or desert pavement destruction and vegetation removal $[3-5,17,20]$. Shading from photovoltaic arrays and heliostats may induce changes in local plant communities by decreasing temperature and moisture evaporation $[4,17,21,22]$. Significant ground water evaporation occurs in desert basins. Coverage of a large percentage of the basin by photovoltaic arrays or heliostats may significantly decrease evaporation rates resulting in a rise in the local water table [3, 4]. Both systems may adversely affect larger wildlife species by interfering with grazing patterns $[4,11,22]$. Heliostat glare could affect bird navigation and the concentration of energy near the receiver may burn flying species passing too close [3].

Photovoltaic plants will emit no gaseous or particulate pollutants, liquid wastes or solid wastes (except under atypical conditions such as outgassing of toxic compounds during a fire) $[5,11,22,23]$. Although the plant releases no thermal pollutants per se, large array collections may function as "heat islands" via reflection of sunlight $[5,21]$. This effect is anticipated to be minimal since maximum sunlight collection (and thus, minimal, reflection) is strived for in array designs. Silicon and CdS photovoltaic plants will require only negligible amounts of water for panel cleaning. Thus, there is little potential for polluting local water systems. Optically. concentrating GaAs systems will require water to cool panel frames supporting the cells to $50^{\circ} \mathrm{C}$ to $100^{\circ} \mathrm{C}\left(122^{\circ} \mathrm{C}\right.$ to $\left.212^{\circ} \mathrm{F}\right)$. System designs presently utilize a recirculating process, thereby minimizing water input requirements and releases [5, 11].

Solar thermal central receiver systems emit no particulates, sulfur dioxide, or nitrogen oxides [6, 10, 21]. However, all systems require a working fluid and a cooling loop. In addition, many designs incorporate an energy storage subsystem often comprised of eutectic salt or heat transfer oils toxic to wildlife. Leakage of working fluids or storage media may adversely affect local water quality. Cooling loops can utilize either wet or dry cooling towers. Drift from wet cooling towers will affect local air quality since it will contain chemicals, such as algicides and anticorrosive compounds [17, 24]. However, because of water constraints in the Southwest, future commercial facilities in that region may be forced to utilize dry cooling towers $[3,4,17]$.

WEC units will also emit no air or thermal pollutants. Since WEC operation does not require water, no water pollutants will be released. In addition, WECs generate no hazardous wastes $[1,7,19,22,25,26]$. However, installation of a large number of WEC units may affect local microclimate by altering windflow patterns. Changes in wind speed and turbulence will affect relative humidity, vapor pressure, evaporation rate and temperature. No field data on microclimate alterations are available although monitoring studies are underway. WEC units are expected to behave similar to windbreaks and transmission towers or other large towers. Speed reductions for an incoming wind velocity of $8 \mathrm{~m} / \mathrm{s}$ (meters $/ \mathrm{sec}$ ) are estimated to be at maximum $2.7 \mathrm{~m} / \mathrm{s}$; at incoming velocities of $11 \mathrm{~m} / \mathrm{s}$ or greater, reductions should be minimal. In addition to slight alterations in local microclimate, WEC units will also affect downwind deposition of snow and leaf litter. Long-term changes in snow deposition will probably affect relative 
composition of plant communities. Small mammal populations may be favored by changes in leaf litter deposition by being provided additional shelter [27].

The most significant environmental effect of WEC operation may be collision hazards to flying species. The potential for collision depends on several factors: (1) solidity of the rotor design; (2) airfoil design; (3) number of organisms within the disk area; (4) behavior of the organisms; (5) weather and wind conditions; and (6) total structure height. Bright lights and tall structures tend to visually disorient birds, causing them to collide with the tower or the ground. Most susceptible to collision are night migrants, especially songbirds migrating at altitudes of 150 to $450 \mathrm{~m}$ (meters). Birds alter altitude depending on terrain and weather conditions and of ten cross ridges (favorable WEC sites) at altitudes far below $150 \mathrm{~m}$. Assuming a bird flying through the rotor disk area takes no evasive action, chance for collision is $13 \%$ if flight speed is $3.5 \mathrm{~m} / \mathrm{s}$ and $6 \%$ if flight speed is 8 $\mathrm{m} / \mathrm{s}$. Songbird flight typcially averages 7 tn $12 \mathrm{~m} / \mathrm{s}$ and that of waterfowl and shorebirds 15 to $25 \mathrm{~m} / \mathrm{s}$ [27]. Collision hazards have been minimal to negligible at present WEC installations, and are not believed to be a significant risk area. It should be noted that birds flying through the MOD-O WEC disk area have been observed to take evasive action [28]. Bat collision probability is projected to approximate that at other tall structures. Collisions at a $1,000 \mathrm{ft}$ television tower in Florida average one to two per year (maximum 5). Probability of insect collision with. WEC rotors has been estimated at $8 \%$ for a flight speed of $3.5 \mathrm{~m} / \mathrm{s}$. Collision probability decréases as insect flight speed increases [27]. 


\section{SECTION 5.0}

\section{ENVIRONMENTAL EFFECTS OF PLANT DECOMMISSION}

Plant decommission is comprised of two activities: (1) disassembly and removal of system components; and (2) reclamation of the plant site. Disassembly of photovoltaic, WEC, and central receiver plants will require use of heavy construction equipment. As such, decommission activities will produce many of the effects characteristic of the plant construction phase; e.g., noise, fugitive dust, worker refuse, (see Section 3.0).

Decommissioned plant components can either be disposed of or recycled. Since silicon is environmentally stable and not toxic, spent Si-photovoltaic cells can be crushed and landfilled with negligible hazard to wildlife or humans. Cells may be recycled, which would involve repurification, recrystallization, and refabrication [5]. Because of their composite nature, CdS cells are difficult to recycle given current technology. Spent cells can be landfilled but only at sites not subject to acid drainage which can leach cadmium and contaminate local waterways [5, 14]. Disposal and recycle methods for GaAs cells have received very little attention, although recyclization methods used by the liquid emitting diode industry may be amenable to GaAs cells. Decommission of a 1 $\mathrm{GW}_{\mathrm{e}}$ facility will require disposal or recycle of $1,700 \mathrm{MT}(1,875 \mathrm{~T})$ methacrylate polymer (from concentrating Fresnel lenses) and 50 to $250 \mathrm{MT}$ (55 to 275T) GaAs cells [5].

Decommission of WEC and central receiver plants will generate no exotic compounds. Many of the solid wastes are amenable to recycling; e.g., aluminum, steel, copper and glass. Disassembly of ten $1.5 \mathrm{MW}$ WEC units and one $5 \mathrm{MW}$ central receiver will generate an estimated $9,977 \mathrm{MT}(11,000 \mathrm{~T})$ solid waste which would require 0.2 hectare (0.4 acre) of sanitary landfill if no recycling occurs [18, 19]. Decommission of photovoltaic array supports and associated structures will also generate waste aluminum, steel, and copper which can be recycled. Considerable quantities of concrete (and possibly asphalt) remaining after decommission of all three solar energy options will probably be landfilled.

Reclamation requirements will probably be fairly site specific. Revegetation of decommissioned sites may be difficult for photovoltaic and central receiver plants deployed in fragile desert environments. Plant communities favored by microclimate changes attributable to photovoltaic arrays and central receiver heliostats may undergo changes due to intensive sunlight, higher temperatures, and lower relative humidity. However, through proper management techniques, original plant communities can (in most cases) be restored at decommissioned șites. 


\section{SECTION 6.0}

\section{CONCLUSIONS}

The previous sections of this paper illustrate that the three solar energy technologies examined are not environmentally benign. Because of their materials-intensive nature, most of the life-cycle environmental effects occur during extraction and processing of resour ces into system components. By contrast, conventional fossil fuel energy technologies pose most of their life-cycle environmental hazards during the plant operation phase via emissions such as particulates, sulfur oxides, nitrogen oxides, and hydrocarbons, and during extraction and processing of fuel the plant requires throughout its 20 to 30 year lifetime. The most obvious environmental benefit of deploying solar electric technologies is displacement or avoidance of adverse environmental impacts associated with nonsolar energy alternatives. Although adverse impacts occur during manufacture of solar energy system components, life-cycle impacts are generally less than those of conventional power plants $[10,19,21]$. For example, Table 6-1 presents data on estimated life cycle emissions from a Si-photovoltaic plant and an advanced, "clean" (99+\% sulfur removal), coal plant. Cumulative life-cycle release of criteria air pollutants from the coal plant clearly outweigh those released from manufacture of components needed to construct the Si-photovoltaic plant. A similar situation occurs for WEC and central receiver systems. Although wide-scale deployment of solar options will produce environm ental effects, the cumulative effects of coal extraction and combustion outweigh the effects of materials extraction and processing for the selected solar technologies. 


\section{TABLE 3}

COMPARISON OF COAL AND SI-PHOTOVOLTAIC CELL POWER PLANTS

$\frac{\text { Parameter }}{\text { Total Land }}$

Land for site

Water

Fue 1

Energy Payback

Air Pollutants

(tons/Mveyr)

particuiates

No $x$

$\mathrm{SO}_{x}$

hyó rocarbons

Co

aldehydes

torit metale

$$
\begin{aligned}
& \frac{\text { Coal Plant }}{3500 \mathrm{~m}^{2} / \mathrm{MW}_{\text {eyr }}} \\
& 1.5-1.9 \mathrm{mi} \\
& 0.5-9.2 \times 10^{6} / \mathrm{MW}_{\mathrm{yr}}{ }^{3} \\
& 3500 \mathrm{~T} / \mathrm{MW}_{\text {eyr }}
\end{aligned}
$$

1.95 years

$4.8-44.9$

$14.3-28.4$

$22.1-41.9$

$\cdot 0.8$

$0.6-2.4$$$
-
$$

0.0 .2

\section{Si-Photovoltaic} Plant

$5400 \mathrm{~m}^{2} / \mathrm{MW}_{\mathrm{evr}}$

$2.25-3.4 \mathrm{mi}^{2}$

$0.6 \times 10^{6} / \mathrm{MW}_{\mathrm{eyr}}$

$350 \mathrm{MT} / \mathrm{yr}^{4}$

5.08 yrs

10,15

$11.2^{5}$

29.

29

29

29

29

$0.02^{5}$

29

29

1 The coa! facility is assued to be a "clean" plant with $99+\%$ sulfur removal. It is also assumed that legislation directed toward reclamation is strictly enforced.

2 Larger number is the water requirement for wet cooling towers.

4 Wate: necessary to clean panels every 5 days.

4 Fuel for $10 \%$ coái backup. 5 Emissions occur during component manufacture, nct during system
operation. 


\section{REFERENCES}

1. Coty, U. A. Wind Energy Mission Analysis, Final Report. CA: Lockheed-California Company; September 1976.

2. Curto, P. "Systems Descriptions and Engineering Costs for Solar-Related Technologies." Solar Thermal Systems. Vol. V. McLean, VA: MITRE Corporation; June 1977.

3. Davidson, M.; Grether, D.; Horowitz, M. Assessment of the Socio-Economic and Environmental Aspects of the Central Receiver Power Plants. Berkeley, CA: Lawrence Berkeley Laboratory.

4. Davidson, M.; Grether, D. The Central Receiver Power Plant $\Lambda$ n Environmental, Ecological, and Socioeconomic Analysis. Berkeley, CA: Lawrence Berkeley Laboratory; June 1977.

5. Division of Solar Energy, Energy Research Development Agency. Solar Program Assessment: Environmental Factors Photovoltaics. Washington, DC: $\cdot$ ERDA; March 1977; ERDA 77-47/43.

6. Division of Solar Energy, Energy Research Development Agency. Solar Program Assessment: Environmental Factors Solar Thermal Electric. Washington, DC: ERDA; March 1977; ERDA 77-47/4.

7. Division of Solar Energy, Energy Research Development Agency. Solar Program Assessment: Environmental Factors Wind Energy Conversion. Washington, DC: ERDA; March 1977; ERDA 77-47/6.

8. Bureau of Mines, U.S. Department of Interior. Mineral Facts and Problems. Bulletin 667. Washington, DC: U.S. Dept. of Interior; $1 \overline{975 .}$

9. Garate, J. A. Wind Energy Mission Analysis, Final Report. General Electric Co.; February 18, $19 \overline{77 .}$

10. Herrera, G., ed. Assessment of RD\&D, Resources, Health and Environmental Effects, O\&M Costs, and Other Social Costs for Conventional and Terrestrial Solar Electric Plants. Jet Propulsion Laboratory; January 7, 1977.

11. Sears, D. R.; McCormick, P. O. Preliminary Environmental Assessment of Solar Energy Systems. Lockheed Missiles and Space Co., Inc.; August 1977; EPA-600/7-77-086.

12. Johnson, L. R.; Simmons, G.; and Peterson, J. Northwest Energy Policy Project, Study Module III-B, Energy Supply and Environmental Impacts, Final Report. Moscow, ID: University of Idaho, Colleges of Forestry and Engineering; 1977.

13. Sittig, M. Environmental Sources and Emissions Handbook. Park Ridge, NJ: Noyes Data Corp.; 1975.

14. Fleischer, M. "Environmental Impact of Cadmium: A Review by the Panel on Hazardous Trace Substance." Environmental Health Perspectives. pp. 253-323; May 1974. 
15. Gandel, M. G.; et. al. Assessment of Large-Scale Photovoltaic Materials Production. Lockheed Missiles and Space Co., Inc,; August 1977; EPA-600/7-77-087.

16. Am erican Conference of Governmental Hygienists. TLV's: Threshold Limit Value for Chemical Substances in Workroom Air. ACGH; 1975.

17. Sears, D. R.; Merrifield; D. V.; and Perry, M. M. Environmental Impact Statement for a Hypothetical 1000 MWe Photovoltaic Solar-Electric Plant. Lockheed Missiles and Space Co., Inc.; August 1977; EPA-600/7-77-085.

18. MITRE Corp. Preliminary Environmental Assessment Concerning the Construction and Operation of a 5-MW Solar Thermal Central Receiver Test Facility. McLean, VA: MITRE Corp.; November 28, 1975.

19. MITRE Corp. Preliminary Environmental Assessment Concerning the Construction and Operation of a Multi-Unit Wind Energy Pilot Plant. McLean, VA: MITRE Corp.; November 28, 1975 .

20. Patten, D. T. "Ecological Impacts of Solar Energy Conversion." (unpublished paper) Tempe, AZ: Arizona State University; 1976.

21. Davidson, M.; Grether, D.; and Wilcox, K. Ecological Considerations of the Solar Alternative. Berkeley, CA: University of California; February 1977; LBL-5927.

22. Beall, S. E.; et. al. An Assessment of the Environmental Impact of Alternative Energy Sources. Oak Ridge National Laboratory; September 1974; ORNL-5024.

23. Brouns, R. J. Environmental Impacts of Nonfusion Power Systems. Battelle Pacific Northwest Laboratory; September 1976.

24. U.S. Dept. of Energy. Environmental Development Plan (EDP), Solar Thermal Power Systems. Washington, DC: U.S. DOE; March 1978.

25. Sessler, G.; and Cukor, P. M. Pollutant Releases, Resource Requirements, Costs, and Efficiencies of Selected New Energy Technologies. Teknekron, Inc.; December 1975.

26. Todd, C. J.; et. al. Cost-Effective Electric Power Generation from the Wind. Denver, CO: Bureau of Reclamation, U.S. Dept. of Interior; August 1977.

27. Rogers, S. E.; et. al. Evaluation of the Potential Environmental Effects of Wind Energy Systems Development. Battelle-Columbus Laboratory; August 1976.

28. U.S. Dept. of Energy. Environmental Development Plan (EDP), Wind Energy Conversion. Washington, DC: U.S. DOE; March 1978.

29. Caputo, R. An Initial Comparative Assessment of Orbital and Terrestrial Central Power Systems, Final Report. CA: Jet Propulsion Laboratory; Calif. Institute of Technology; March 1977.

30. Argonne National Laboratory. A Study of Social Costs for Alterantive Means of Electuric Puwei Generation for 1980 and 1990. Argonne National Laboratory; February 1973. 